\title{
Assessment of Epidemic Potential of Soybean Rust in the United States
}

\author{
S. Pivonia and X. B. Yang, Department of Plant Pathology, Iowa State University, Ames 50011; and Z. Pan, \\ Department of Earth \& Atmospheric Sciences, St. Louis University, St. Louis, MO 63103
}

\begin{abstract}
Pivonia, S., Yang, X. B., and Pan, Z. 2005. Assessment of epidemic potential of soybean rust in the United States. Plant Dis. 89:678-682.

This article assesses the epidemic potential of soybean rust (Phakopsora pachyrhizi) in the United States. In the assessment, there are three critical components of uncertainty: (i) suitability of climate conditions in production areas for soybean rust epidemics; (ii) likelihood of establishment of the fungus in North America; and (iii) the seasonal dispersal potential of the pathogen from overwintering regions to major soybean production regions. Assessments on the first and second components suggest soybean rust epidemics are likely in the United States, and the certainty of the third component is yet to be determined. Comparison of epidemiological factors for soybean rust in soybean production regions between China and the United States shows a complicated picture with the United States having factors that both increase and decrease risk. Future investigation of risk components-incipience in the field and long-distance dispersal—is needed.
\end{abstract}

A disease risk analysis typically consists of scientific estimations of the likelihood of establishment and magnitude of epidemics. Risk assessment of soybean (Glycine max) rust, caused by the fungus Phakopsora pachyrhizi, has contributed to the development of these general concepts and quantitative methodology. Epidemiologically, risk assessment of soybean rust consists of three major components: (i) conditions for disease occurrence, (ii) establishment after entry, and (iii) dispersal. The first component addresses suitability of climate in production areas for epidemics. If conditions are not suitable, no further assessment is needed. The second component determines whether and where the pathogen can survive the winter in North America. The third component consists of two subcomponents: entry likelihood of $P$. pachyrhizi into North America and establishment of northward dispersal pathways during the production season. Numerous studies have addressed conditions for soybean rust occurrence (14,15,17,30,33-37) and, more recently, establishment after entry (24). In this article, we review these assessments and discuss the dispersal and entry potential of $P$. pachyrhizi into North America and sea-

Corresponding author: X. B. Yang

E-mail: xbyang@iastate.edu

Accepted for publication 8 December 2004.

DOI: 10.1094/PD-89-0678

(C) 2005 The American Phytopathological Society sonal dispersal potential from the overwintering region to major soybean production regions in the United States.

\section{Climatic Conditions for Soybean Rust Occurrence}

Before the early 1990s, studies of risk assessment of soybean rust conducted by the United States Department of Agriculture Foreign Disease and Weed Science Research Unit, located at Fort Detrick, MD, focused on environmental conditions in the U.S. soybean production region and their suitability for the disease. Research efforts were divided into two phases: (i) understanding epidemiology and crop loss to soybean rust based on research in the containment facility at Fort Detrick and in fields in Asia, which provided a basis for disease modeling; and (ii) quantifying, through computer modeling, the potential effects of rust on soybean yield in the United States.

Studies in containment. Fort Detrick has a facility that represents the highest level of containment for plant pathogen research (18). Research in the containment facility focused on determining the importance of each component or subcomponent in the soybean rust disease cycle, and on quantifying its response to host and environmental variation. The componentsspore germination, infection, latent period, lesion expansion, sporulation, and senescence of uredia-were studied by several researchers $(14,15,17)$. The effects of dew duration and temperature on infection have been quantified as a two-dimensional relationship from which an infection model was developed to estimate infection (34). Other models evaluated the effects of latent period, lesion expansion, and infection period (34). These studies provided critical background information for building epidemiological models for risk assessment.

Field experiments in Asia. A cooperative agreement between Fort Detrick and the Asian Vegetable Research and Development Center in Taiwan was established in 1979 to study soybean rust epidemics in field plots. Southern Taiwan was ideal for field studies because soybean is grown year-round, which allowed analysis of the effect of seasonal environmental variation on rust epidemics, and because the climate in Taiwan is similar to that in some southern areas of the United States. Many epidemiological experiments were conducted there. Among them is a 2-year sequential weekly planting experiment (total 73 plantings) that greatly contributed to our understanding of soybean rust epidemiology $(30,36)$. The weekly planting created a series of environmental windows, resulting in various types of epidemics $(39,36)$. In that experiment, the seasonal differences in epidemics may resemble geographic differences in terms of weather effects. Extensive crop loss studies were conducted as well in Taiwan and provided information for modeling the impact of soybean rust on yield. These experiments were conducted with six cultivars differing in rust resistance, and the effects of disease were measured at four levels: (i) indirect yield components, (ii) direct yield components, (iii) plant yield, and (iv) plot yield. The study showed that although the disease affected many plant growth processes, such as shoot growth, pod development, and seed growth, the closest relationship between disease and crop response was green leaf area duration and plot yield. Thus, the green leaf area was the best link between a disease model and a soybean growth model to reflect disease effects correctly (35).

Disease modeling. A simulation model, SOYRUST (34), was developed using the data collected from Fort Detrick and Taiwan. This simple disease model includes most weather variables that influence disease epidemics. It consists of a main program, input and preprocessing modules, and graphic and statistical output packages. The model was validated with data 
from 69 sequential planting experiments during 1980 and 1981 in Taiwan, and the model predictions matched the observations well. The accuracy of the model was demonstrated by high correlations between predicted and observed data. In validation with data not used for model development, the model predicted well the disease development during the regular season (34).

Occurrence likelihood. SOYRUST was integrated, as a subroutine, into the soybean growth model SOYGRO, developed at the University of Florida (31) to simulate disease progress during the production season and predict yields. With an assumption that spores of $P$. pachyrhizi are available early in the growing season, the simulation results showed that considerable yield losses could occur in some areas of the United States, particularly in the southeast. In one simulation using 1976 to 1988 data from Gainesville, FL, yields predicted in the absence of the disease fit the measured yields well, and predicted losses due to rust varied from 5 to $48 \%$ (33). Simulations suggested that high summer temperatures may retard disease development, whereas cooler summer temperatures favor disease development.

\section{Year-round Establishment Likelihood}

The risk assessments for soybean rust assumed that within a location, spores are available before flowering (33), an assumption that may not be true each year. Predicting the year-round survival of $P$. pachyrhizi in North America is important for determining both the availability of spores in the spring and potential dissemination into major soybean production regions during a growing season from an overwintering area. Models were used to predict where climatological conditions are suitable for the year-round persistence of P. pachyrhizi. These regions might serve as source areas for seasonal epidemics. Longterm meteorological averages were used to assess temperature stress, utilizing CLIMEX software developed by Sutherst and Maywald (28), and moisture stress was determined using a procedure developed in the study. Integration of stresses was used to predict the likelihood of survival of $P$. pachyrhizi within a location (24).

Global soybean production areas can be divided into two types: (i) areas where the pathogen can survive year-round on suitable hosts, and (ii) areas where occurrence depends on external sources of inoculum after long-distance dispersal from a source area. Most areas where soybean rust has been reported are of the former, including parts of the Eastern Hemisphere such as southern China, eastern Australia, and Indonesia, and areas in Africa and South America. Areas presumed suitable for year-round survival of $P$. pachyrhizi in the Western Hemisphere extend from southern
Brazil to south Texas and Florida (Fig. 1). If $P$. pachyrhizi enters the United States, the fungus is likely to overwinter in areas where climatic conditions in winter are similar to those in southern China. If a less conservative modeling approach is used, the Gulf of Mexico is also in the $P$. pachyrhizi year-round survival zone.

The areas where $P$. pachyrhizi does not overwinter, but is known to impact soybean yields, are in the Eastern Hemisphere. These areas include parts of China, up to approximately latitude $37^{\circ} \mathrm{N}$ (29) and southern Japan (12). Soybean production regions in the United States (excluding Florida and southern Texas) and central Argentina are the other main soybean production areas where rust could not overwinter but may occur during a growing season because of their proximity to a potential rust overwintering zone.

Overwintering and seasonal epidemics. In areas where winter conditions limit rust pathogen survival, overwintering ranges would vary from year to year. Information is limited on the relationships among fungal overwintering, disease incipience, and epidemic severity during a growing season for rusts. A relationship between winter survival and yield losses from research plots was shown by Eversmeyer and Kramer (9) for wheat leaf rust. Wheat yield losses due to wheat leaf rust (Puccinia triticina) infection were greater than 2\% in Manhattan, KS, during 1980 to 1993, when the rust survived the winter. However, losses would have been lower than $2 \%$ if the rust had not overwintered.
In regions of China where $P$. pachyrhizi overwintering is predicted, severe epidemics are common in winter on Hainan Island and in spring and fall on the southeastern coast of China. In areas where soybean rust occurs but does not overwinter, severe epidemics occur mainly in fall (29).

\section{Regional Spread \\ in a Growing Season}

Wind disperses many rust pathogens, during the growing season, from source regions to areas where year-round survival does not occur (19). Dissemination of spores from source to target areas can occur during a growing season in comparatively short hops, leading to a gradual movement of the disease front, as suggested for wheat stem rust in the United States (5). Alternatively, dissemination can occur in one long stretch, as suggested for wheat stem rust spore movement from southern to central India (20).

Soybean rust impact on yield as related to incipience in the field. In general, when environmental conditions are suitable for a polycyclic disease, the earlier the infection starts, the more severe the disease is at the end of the season. In southwestern Japan for example, if soybean rust incipience for autumn soybean, planted in the last week of June, was before 20 September, yield losses were substantial. Yield losses were light or nil if the inception of rust occurred after the end of September (12). In Korea, where soybean is mainly planted in May, soybean rust is not a major problem because it usually first appears in

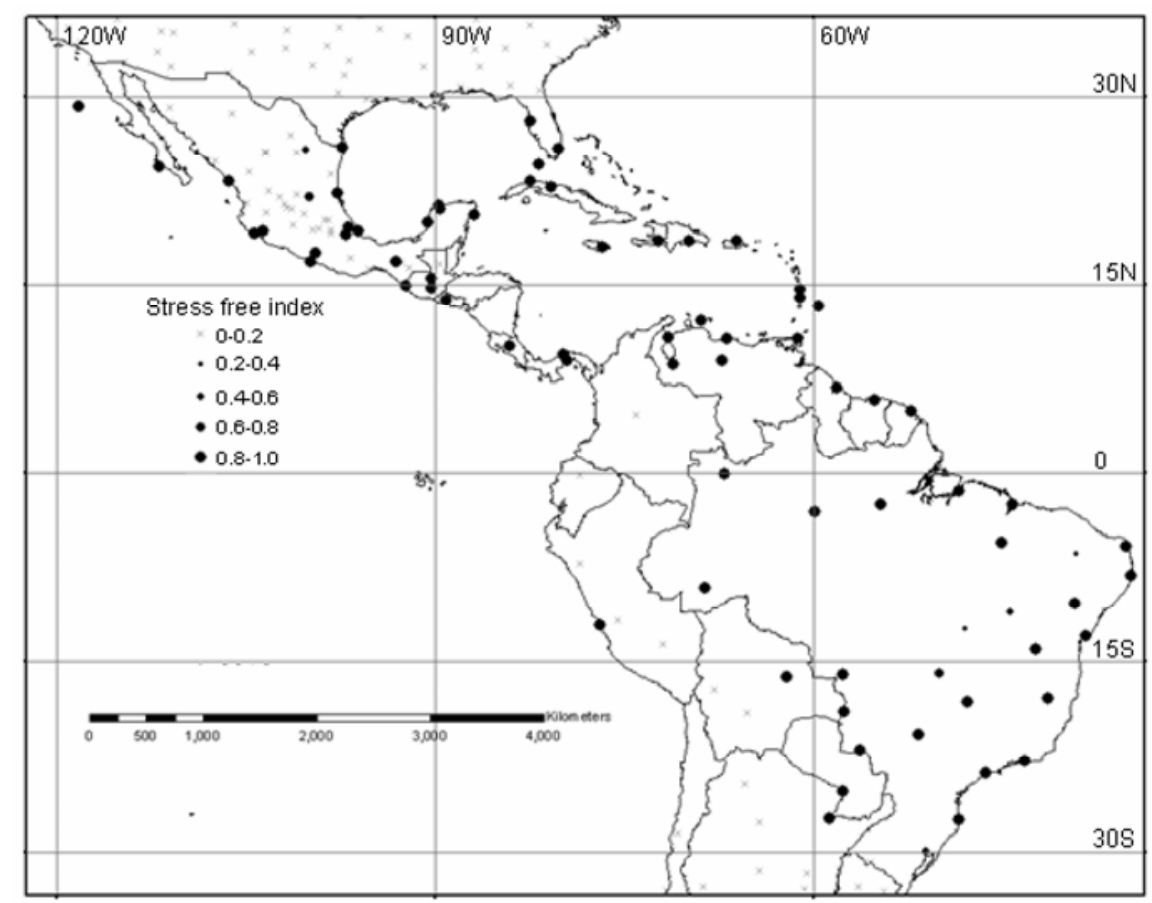

Fig. 1. Map of the stress-free (year-round survival) index for Phakopsora pachyrhizi in regions between South America and North America. The stress-free index is scaled (as indicated by dot size) between 0 and 1, where 0 indicates locations where temperatures and/or dry conditions prevent the fungus from growing year-round, and 1 indicates locations free of stresses, where rust can occur yearround. 
mid-September (3). In Taiwan, inoculation of $P$. pachyrhizi at early R5 soybean stage (6) resulted in heavy yield losses (up to $50 \%$ ) in the spring and lighter losses in autumn (approximately 10\%) compared with fungicide-protected plots. Earlier inoculations, at growth stages R1 or R3, increased yield losses (9).

Seasonal spread in China. China has a land area similar to that of the United States, and there soybean is grown at latitudes 19 to $52^{\circ} \mathrm{N}$. Soybean rust occurs in China every year. The pathogen is thought to overwinter in southern coastal areas (29) and spread northward by winds as the growing season progresses. Tan et al. (29) classified Chinese soybean production regions into three areas in terms of losses: (i) severe epidemic regions, where the disease occurs annually with yield losses of 30 to $50 \%$; (ii) medium-epidemic regions with loss of 11 to $30 \%$; and (iii) light-epidemic regions with losses of 5 to $10 \%$. Geographically, Tan et al. (29) classified soybean production into three zones: (i) severe epidemic (south of latitude 18 to $27^{\circ} \mathrm{N}$ ); (ii) frequent occurrence (south of latitude 27 to 35 , to $37^{\circ} \mathrm{N}$ ); and (iii) occasional occurrence (from $37^{\circ} \mathrm{N}$ to northern production region) (Fig. 2).

These two sets of classifications (frequency-based and loss-based) do not necessarily coincide each year. In frequent occurrence regions, severe epidemics can occur. For example, severe epidemics occurred in 1975 and 1983 in Hunan Province $\left(25\right.$ to $\left.30^{\circ} \mathrm{N}\right)$, with re- ported yield losses more than 50\% in 1975. In the occasional occurrence region, a moderate epidemic (11 to $30 \%$ yield losses) occurred in Shandong Province (latitude 34 to $37^{\circ} \mathrm{N}$ ) in 1993 . For the northern main soybean production regions (latitude 40 to $50^{\circ} \mathrm{N}$ ), although rust occurs there, we have found no records of outbreaks. Data from China indicate that the disease can spread over a large latitude range, with damage level and occurrence frequency decreasing northward. Care must be taken when comparing the soybean rust potential in China with the United States because soybean in China has a longer growing season. Seasonal wind patterns are also different between the two countries.

Seasonal long-distance dispersal of plant pathogens in the United States. The wind pattern in North America is very favorable for northward transport of pathogens. In particular, the south-central United States and the Great Plains are the home of the nocturnal low-level jet, a strong southerly wind belt. During the growing season, the low-level jet does not occur, at least not as prominently, elsewhere in the world, including China $(22,23)$. This low-level jet was found to be responsible for the migration in spring of the black cutworm (Agrotis ipsilon) from southern Texas into Iowa (10).

Despite the suitability of wind patterns for long-distance dispersal from south to north, different diseases can vary in timing of occurrence and in expansion rate. Dis-

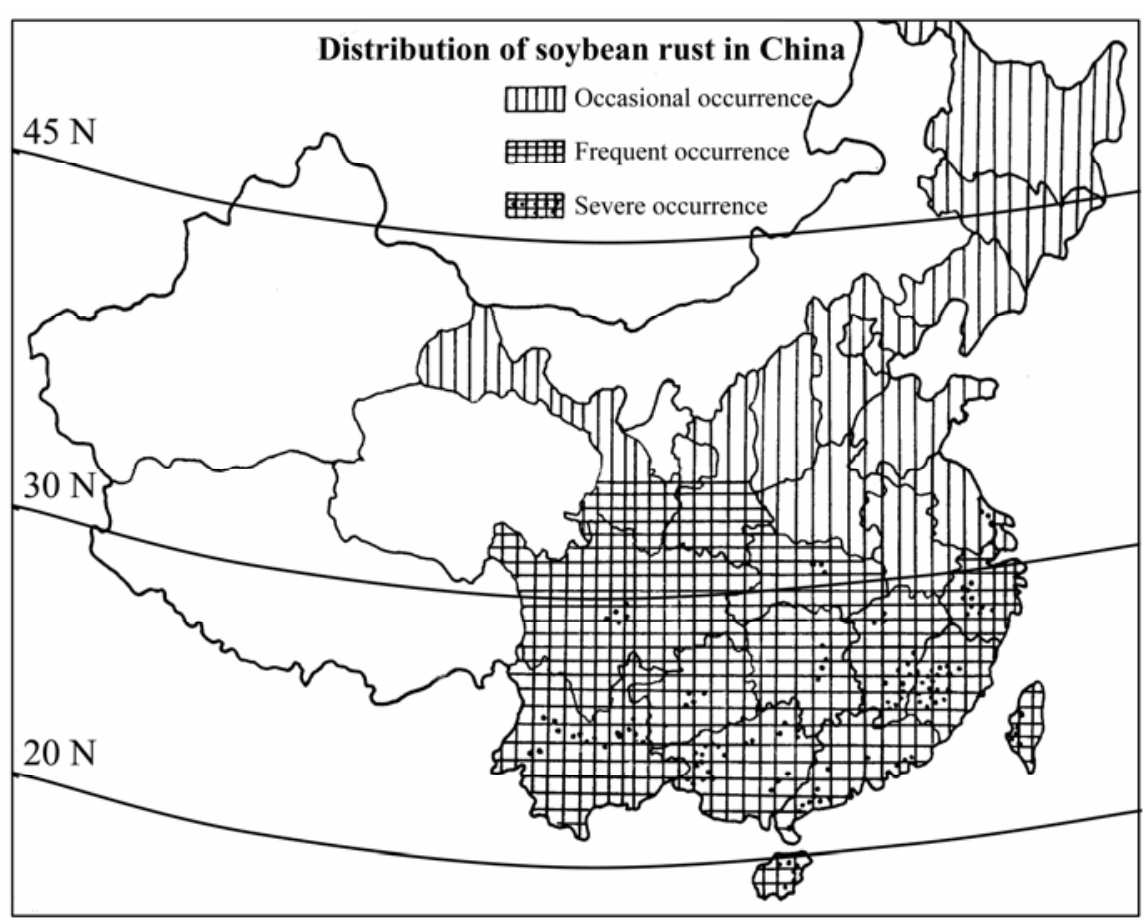

Fig. 2. Distribution of soybean rust occurrence in China (modified from Tan et al. [29]). Geographically, soybean production regions are: severe epidemic regions (squares with dots); frequent occurrence regions (squares); and occasional occurrence regions (stripes). In severe epidemic regions, severe epidemics occur frequently. In frequent or occasional occurrence regions, disease occurs frequently or occasionally with variable severity. eases that have a potential for a seasonal northward expansion pattern in the United States can be divided into three groups: (i) diseases that frequently occur early in the summer, (ii) diseases that frequently occur late in the summer, and (iii) diseases that rarely or never occur, although found in countries south of the United States.

Two well-documented pathogens capable of long-distance dispersal and that frequently occur early are wheat stem rust (Puccinia graminis f. sp. tritici) and tobacco blue mold (Peronospora tabacina). Observed time for first occurrence of these diseases over years shows a gradual southto-north expansion pattern, suggesting that their long-distance dispersal in the United States is characterized more by "shorthop" movements rather than by "grand leaps." Average first occurrence of wheat stem rust over a 40-year period ranged from 1 May in north-central Texas to 24 June in southeastern North Dakota (7). The calculated daily disease front movement from Texas to North Dakota is approximately $30 \mathrm{~km} /$ day. The northward daily front movement rates of tobacco blue mold from northern Florida or southern Georgia to Pennsylvania, as calculated from 9 years of data (1,13), are between 10 and 20 $\mathrm{km} /$ day.

Southern rust (Puccinia polysora) of corn (Zea mays) and groundnut rust (Puccinia arachidis) of peanut (Arachis hypogaea) are pathogens frequently occurring in late summer in the southern United States and even later farther north, but they rarely impact yield. Although environmental conditions are suitable for the occurrence of southern rust in many regions throughout the Corn Belt (16), and inoculation in Maryland and Pennsylvania demonstrated its destructive potential in fields (25), southern rust rarely impacts yield, except in the southern United States. Southern rust usually occurs in Mississippi between mid-July and early August and occasionally reduces yields of late-planted corn (11). In a 4-year survey in Indiana, southern rust incipience date was between 21 August and 27 September (26). Although data are limited in time and absent for other locations between Mississippi and Indiana, if we assume a short-hop rust movement pattern, the lag time in southern corn rust incidence resembles the daily frontal movement rate of wheat stem rust. Groundnut rust can be found almost every year in Texas and Georgia and less frequently in North Carolina and Virginia. However, outbreaks are usually late and are considered a significant factor for crop losses mainly in late-planted fields in southern Texas (8).

Tropical rust (Physopelle zeae) of corn and the New World soybean rust (Phakopsora meibomiae) are examples of diseases rarely or not yet occurring in the United States, although they are found in the Caribbean, Mexico, and Central and South 
America $(2,16)$. The former disease was reported to occur once in southern Florida (27), and the latter has yet to be observed in the United States.

Similar to the situation in East Asia, soybean rust might be suitable for a seasonal long-distance dispersal in the United States. South-to-north dispersal rate of the disease might fluctuate annually depending on weather conditions related to longdistance dispersal transport and disease development in the overwintering and nonoverwintering areas. However, if established, timing of disease incipience in the southern United States will probably play a major role in incipience of soybean rust farther north across the soybean belt. A better understanding of biological and climatological factors related to occurrence of long-distance dispersal of plant pathogens in the southern United States should aid in predicting potential soybean rust epidemics.

Comparison of risk factors between China and the United States. China and the United States have similar geographical size and latitude range for soybean production (32). P. pachyrhizi overwinters in southern China, and the potential overwintering area in the United States is also in the south (Fig. 3). If $P$. pachyrhizi is established in North America, soybean rust epidemics are expected to depend on the long-distance dispersal of spores northward from the southern areas, potentially in a similar way to the spread of epidemics in China. Therefore, we can cautiously assess soybean rust risks to the United States based on China's experience with the disease. Below, we compare the main risk factors affecting soybean rust epidemics between China and the United States in terms of an increased or decreased risk for epidemics.

Overwintering. P. pachyrhizi is assumed to overwinter in a relatively extensive area, in southern China and neighboring countries to the south of China. In the United States, overwintering might be possible in a relatively limited area, such as parts of Florida and southern Texas, and in coastal areas near the Gulf of Mexico during mild winters. In northern and central Mexico, potential overwintering areas are mainly in the eastern costal regions (Fig. 3).

Growing season. Along the southern coast of China, soybean is grown yearround. Soybean rust occurs in winter and spring on Hainan Island and southern Guangdong Province (29). In coastal areas, soybean rust occurs in spring and fall, and the disease usually is observed in summer and fall in the Yangtze River area of central China. Continuous soybean production helps maintain high levels of inoculum. In the United States, soybean is grown almost exclusively as a summer crop, and consequently, the appearance of rust in fields might be delayed.

Wind dispersal in growing seasons. Compared with China, winds in the United States during a growing season are stronger and more southerly due to the north-south orientation of the Rocky Mountains. In particular, the nocturnal low-level jets with high nighttime humidity can facilitate the northward dispersal of P. pachyrhizi. This nocturnal jet during the summer growing season is weaker and less frequent in China.

Alternative hosts. Kudzu (Pueraria lobata) is a very suitable host for P. pachyrhizi $(21,29)$, and its importance to potential soybean rust epidemics in the United States cannot be overestimated. In Paraguay, kudzu is considered an important overwintering host in areas where soybean rust is endemic. Although kudzu originated from China and Japan, it is aggressive and widespread in the United States, covering large areas of the southern to central United States. Kudzu might serve as an overwintering host where its leaves remain green during winters. In regions where $P$. pachyrhizi cannot overwinter, kudzu leaves that grow before soybean emerges in the spring may serve as a bridging host for inoculum increase and northward spread.

\section{Summary}

A disease risk assessment consists of scientific estimation of introduction and establishment of a pathogen in a new area, and the likelihood of epidemics of the disease in the new area. The assessment is a step-by-step process with early assessments built on valid assumptions. For risk assessment of soybean rust in U.S. soybean, there are three major components: (i) whether climate conditions in production areas are suitable for soybean rust epidemics; (ii) likelihood of establishment of the fungus in North America; and (iii) seasonal dispersal potential of the pathogen from overwintering regions to major soybean production regions. Currently, assessments of the first two components suggest a likelihood of occurrence of soybean rust epidemics in the United States. A comparison of several epidemiological factors in soybean production regions between China and the United States yielded an inconclusive picture: two factors indicating an increase in risk, and two other factors reducing risk. Future investigation of the third risk component-incipience in the field and long-distance dispersal-is needed for a comprehensive risk assessment. Results from risk assessment studies can serve as a foundation for regional disease monitoring and prediction.

\section{ACKNOWLEDGMENTS}

We thank the United Soybean Board and USDAARS Foreign Disease and Weed Science Research Unit for support. The third author was partly supported by the DOE/BER Program through Great Plains Regional Center of NIGEC (DE-FC0390ER61010). We are grateful to Jie (Jack) Guan for his assistance. We thank the senior editor and anonymous reviewers for a thorough review of the manuscript.

\section{LITERATURE CITED}

1. Aylor, D. E., Taylor, G. S., and Raynor, G. S 1982. Long-range transport of tobacco blue mold spores. Agric. Meteorol. 27:217-232.

2. Bromfield, K. R. 1984. Soybean rust. Monogr. 11. American Phytopathological Society, St. Paul, MN.

3. Chung, B. J., and Park, C. S. 1977. Soybean

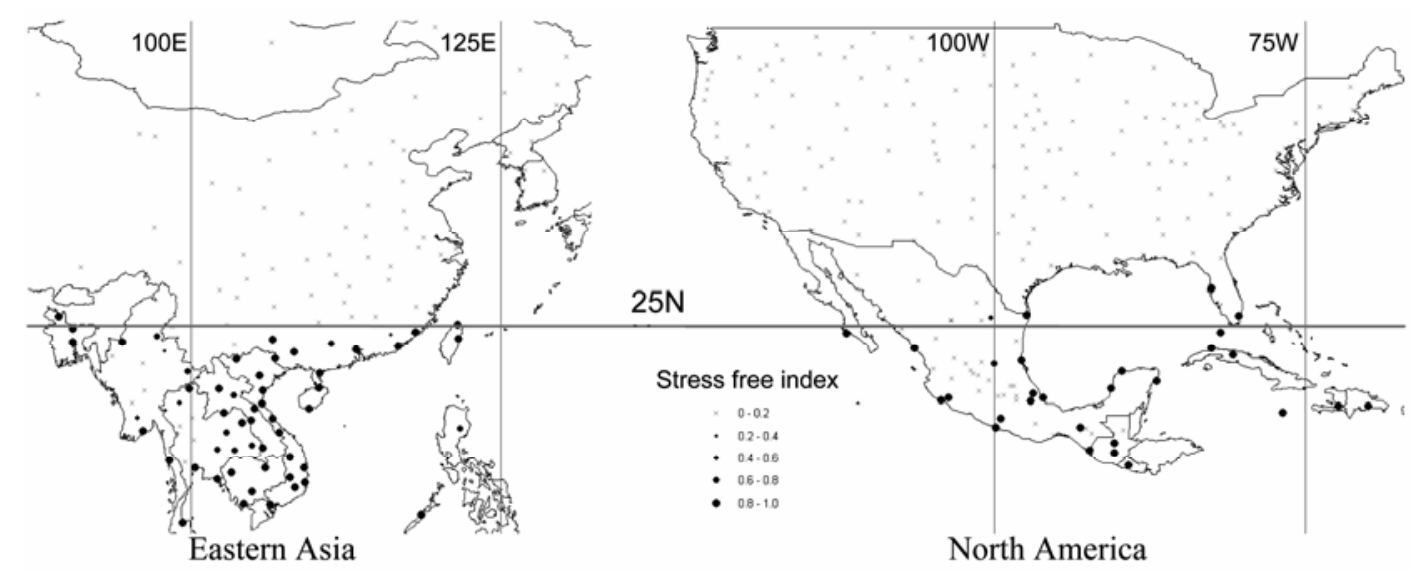

Fig. 3. Comparison of year-round survival potential of soybean rust between North America and Eastern Asia. The stress-free index is scaled (as indicated by dot size) between 0 and 1 , where 0 indicates locations where temperatures and/or dry conditions are expected to prevent year-round growth of the fungus, and 1 indicates a location free of stresses where the rust can occur year-round. 
rust in Korea. Pages 49-50 in: Rust of Soybean the Problem and Research Needs. R. E. Ford and J. B. Sinclair, eds. Coll. Agric. Univ. Ill. INTSOY Series vol. 12.

4. Eversmeyer, M. G., and Kramer, C. L. 1996. Modeling winter and early spring survival of Puccinia recondita in wheat nurseries during 1980 to 1993. Plant Dis. 80:490-493.

5. Eversmeyer, M. G., and Kramer, C. L. 2000. Epidemiology of wheat leaf and stem rust in the central Great Plains of the USA. Annu. Rev. Phytopathol. 38:491-513.

6. Fehr, W. R., Caviness, C. E., Burmood, D. T., and Pennington, J. S. 1971. Stage of development descriptions for soybeans, Glycine max (L.) Merr. Crop Sci. 11:929-931.

7. Hamilton, L. M., and Stakman, E. C. 1967. Time of stem rust appearance on wheat in the western Mississippi basin in relation to the development of epidemics from 1921 to 1962. Phytopathology 57:609-614.

8. Hammons, R. O. 1977. Groundnut rust in the United States and the Caribbean. PANS 23:300-304.

9. Hartman, G. L., Wang, T. C., and Tschanz, A. T. 1991. Soybean rust development and the quantitative relationship between rust severity and soybean yield. Plant Dis. 75:596-600.

10. Hendrix, W. H., III, and Showers, W. B. 1992. Tracing black cutworm and armyworm (Lepidoptera: Noctuidae) northward migration using Pithecellobium and Calliandra pollen. Environ. Entomol. 21:1092-1096.

11. King, S. B., and Scott, G. E. 1982. Development of southern rust on maize at different stages of maturity. Plant Dis. 69:937-939.

12. Kitani, K., and Inoue, Y. 1960. Studies on the soybean rust and its control measure. Part 1. Studies on the soybean rust. Shikoku Agric. Exp. Stn. Bull. 5:319-342.

13. Main, C. E. 1996-2002. Blue mold historical forecasts. North American Plant Disease Forecast Center. N.C. State University. Published online.

14. Marchetti, M. A., Melching, J. S., and Bromfield, K. R. 1976. The effects of temperature and dew period on germination and infection by uredospores of Phakopsora pachyrhizi. Phytopathology 66:461-463.
15. Marchetti, M. A., Uecker, F. A., and Bromfield, K. R. 1975. Uredial development of Phakopsora pachyrhizi in soybean. Phytopathology 65:822-823.

16. Melching, J. S. 1975. Corn rusts: Type, races and destructive potential. Pages 90-115 in: 1975 Proc. Annu. Corn Sorghum Res. Conf. 30 th

17. Melching, J. S., Bromfield, K. R., and Kingsolver, C. H. 1979. Infection, colonization, and uredospore production on Wayne soybean by four cultures of Phakopsora pachyrhizi, the cause of soybean rust. Phytopathology 69:1262-1265.

18. Melching, J. S., Bromfield, K. R., and Kingsolver, C. H. 1983. The plant pathogen containment facility at Frederick, Maryland. Plant Dis. 67:717-722.

19. Nagarajan, S., and Singh, D. V. 1990. Long distance dispersion of rust pathogens. Annu. Rev. Phytopathol. 28:139-153.

20. Nagarajan, S., Singh, D. V., Joshi, L. M., and Saari, E. E. 1976. Meteorological conditions associated with long-distance dissemination and deposition of Puccinia graminis tritici uredospores in India. Phytopathology 66:198203.

21. Ono, Y., Buritica, P., and Hennen, J. 1992. Delimitation of Phakopsora, Physopella, and Cerotelium and their species on Leguminosae. Mycol. Res. 96:825-850.

22. Pan, Z., Arritt, R., Segal, M., Chen, T.-C., and Weng, S.-P. 2000. Effects of quasi-stationary large-scale anomalies on mesoscale features associated with 1993 flood. J. Geophys. Res. 105:29551-29564.

23. Pan, Z., Segal, M., and Arritt, R. W. 2004. Role of topography in forcing low-level Jets in central U.S. during the 1993 flood-altered terrain simulations. Mon. Wea. Rev. 132:396-403.

24. Pivonia, S., and Yang, X. B. 2004. Assessment of the potential year-round establishment of soybean rust throughout the world. Plant Dis. 88:523-529.

25. Raid, R. N., Pennypacker, S. P., and Stevenson, R. E. 1988. Characterization of Puccinia polysora epidemics in Pennsylvania and Maryland. Phytopathology 78:579-585.

26. Schall, R. A., McCain, J. W., and Hennen, J. F.
1983. Distribution of Puccinia polysora in Indiana and absence of cool weather form as determined by comparison with $P$. sorghi. Plant Dis. 67:767-770.

27. Seymour, C. P., and Miller, J. W. 1974. The eradication of two potentially dangerous rusts, Physopella pallescens and $P$. zeae, from Florida. Pages 124-126 in: 1974 Proc. Fla. State Hortic. Soc. Vol. 87.

28. Sutherst, R. W., and Maywald, G. F. 1985. A computerized system for matching climates in ecology. Agric. Ecosyst. Environ. 13:281-299.

29. Tan, Y. J., Yu, Z., and Yang, C. Y. 1996. Soybean Rust. China Agricultural Press, Beijing, China.

30. Tschanz, A. T. 1984. Soybean Rust Epidemiology: Final Report. Asian Vegetable Research and Development Center, Shanhua, Taiwan.

31. Wilkerson, G. G., Jones, J. W., Boote, K. J., and Mishoe, J. W. 1985. SOYGRO, University of Florida, Gainesville.

32. World Agricultural Outlook Board, USDA 1994. Major World Crop Areas and Climatic Profiles. U.S. Dep. Agric. Agric. Handb. No. 664.

33. Yang, X. B., Dowler, W. M., and Royer, M. H. 1991. Assessing the risk and potential impact of an exotic plant disease. Plant Dis. 75:976982.

34. Yang, X. B., Dowler, W. M., and Tschanz, A. T. 1991. A simulation model for assessing soybean rust epidemics. J. Phytopathol. 133:187200.

35. Yang, X. B., Dowler, W. M., Tschanz, A. T. and Wang, T. C. 1992. Comparing the effects of rust on plot yield, plant yield, yield components, and vegetative parts of soybean. J. Phytopathol. 136:46-56.

36. Yang, X. B., Royer, M. H., Tschanz, A. T., and Tsai, B. Y. 1990. Analysis and quantification of soybean rust epidemics from seventy-three sequential planting experiments. Phytopathology 80:1421-1427.

37. Yang, X. B., Tschanz, A. T., Dowler, W. M. and Wang, T. C. 1991. Development of yield loss models in relation to reductions of components of soybean infected with Phakopsora pachyrhizi. Phytopathology 81:1420-1426. 